\title{
Kesan Pigmen Pewarna terhadap Pertumbuhan Sebatian antara Logam Sambungan Pateri Sn-3.0Ag-0.5Cu
}

\author{
(Effect of Coloured Pigment on Intermetallic Compound Growth of Sn-3.0Ag-0.5Cu Solder Joint)
}

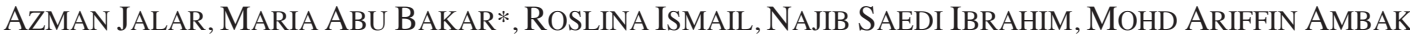

\begin{abstract}
ABSTRAK
Pewarnaan pes pateri membuka suatu ruang kepada keperluan dalam teknologi untuk proses pengenalpastian, penandaan, piawaian, pengujian dan penilaian terhadap antarasambungan pes pateri. Dua jenis pigmen pewarna iaitu hijau $(G)$ dan bercahaya dalam gelap (GD) digunakan untuk mengkaji kesan pewarnaan sambungan pateri ke atas kestabilan antarasambungan pateri Sn-3.0Ag-0.5Cu (SAC 305). Pes pateri tanpa warna digunakan sebagai sampel kawalan untuk membandingkan keputusan kajian. Uji kaji penuaan sesuhu digunakan untuk melihat perubahan pertumbuhan sebatian antara logam (IMC). Pigmen pewarna GD dengan peratusan sebanyak 5\% telah menunjukkan kestabilan pertumbuhan IMC dengan perubahan pertumbuhan yang paling rendah iaitu sebanyak 5.6 um bagi sambungan pateri yang berwarna berbanding dengan peratusan pigmen pewarna yang lebih tinggi dengan perubahan pertumbuhan IMC sehingga 9 um selepas didedahkan kepada penuaan sesuhu pada $150^{\circ} \mathrm{C}$ selama 1000 jam. Walau bagaimanapun, kestabilan pertumbuhan IMC dengan penggunaan pes pateri berwarna adalah lebih rendah berbanding dengan pes pateri tidak berwarna. Maka penambahan pigmen pewarna hendaklah dipertimbangkan dengan mengambil kira kestabilan mikrostruktur dan pertumbuhan lapisan IMC supaya tidak menjejaskan kualiti dan kebolehharapan sesuatu sambungan pateri.
\end{abstract}

Kata kunci: Bahan pateri Sn-Ag-Cu; pateri berwarna; pertumbuhan sebatian antara logam; pigmen pewarna; sambungan pateri

\section{ABSTRACT}

The colouration of solder paste opens up a space for technology requirements for the identification, marking, standardization, testing and evaluation processes of the solder inconnection. Two types of colour pigments, green $(G)$ and glow in the dark (GD) are used to study the effect of coloured solder on stability of solder joint Sn-3.0Ag-0.5Cu (SAC 305). Colourless solder paste is used as a control sample to compare the results of the study. The isothermal aging test is used to observe the growth of intermetallic compound (IMC). GD colour pigment with a percentage of 5\% has shown growth stability with the lowest changes of IMC growth, $5.6 \mu \mathrm{m}$ for coloured solder joint as compared to other higher colour pigment percentage with higher changes of IMC growth up to $9 \mu \mathrm{m}$ after subjected to isothermal aging at $150^{\circ} \mathrm{C}$ for $1000 \mathrm{~h}$. However, IMC growth stability with the use of coloured solder paste is lesser than the colourless solder paste. Therefore, the addition of colour pigments should be considered on the stability of the microstructure and the growth of the IMC layer so that it will not affect the solder joint quality and reliability.

Keywords: Colour pigment; coloured solder; intermetallic compound growth; solder joint; solder material Sn-Ag-Cu

\section{PENGENALAN}

Bahan pateri dan pematerian merupakan teknologi yang menjadi tulang belakang kepada industri pempakejan elektronik. Pelbagai jenis bentuk pateri antaranya ialah wayar, bar, dan pes aloi pateri bebas plumbum telah digunakan dengan meluas dalam industri elektronik dalam teknologi antarasambungan (Bakar et al. 2016). Selari dengan perkembangan teknologi ke arah pengecilan bahan serta produk, maka penggunaan aloi pateri dalam bentuk pes sebagai bahan penyambung komponen elektronik kini telah mendapat perhatian yang tinggi. Pes aloi pateri ialah campuran berkrim antara serbuk aloi pateri bersama fluks dalam nisbah 50:50 (Ren et al. 2016). Fluks terdiri daripada campuran resin yang berfungsi dalam aktiviti fluks, kelekitan dan sawar oksigen, bahan pengaktif bagi meningkatkan aktiviti fluks, bahan pelarut dan bahan tambahan reologi. Pes pateri ini bertindak sebagai gam semasa penempatan komponen dan membentuk antarasambungan elektrik dan mekanik yang kekal selepas proses pematerian. Kajiankajian lepas telah menghasilkan pelbagai komposit pes pateri dengan penambahan bahan lain seperti $\mathrm{CNT}, \mathrm{TiO}_{2}$, $\mathrm{Al}_{2} \mathrm{O}_{3}$, Ni dan sebagainya bagi memanipulasi sifat fizik pempaterian (Ismail et al. 2016; Yahaya et al. 2016). Pes aloi pateri yang digunakan sekarang adalah tidak berwarna. Pewarnaan pes aloi pateri memberikan sesuatu kelainan dalam bidang pematerian. Pewarnaan sambungan pateri boleh menjadi suatu keperluan bagi teknologi pada masa hadapan yang boleh memudahkan proses pengenalpastian, penandaan, piawaian, pengujian dan penilaian terhadap 
antarasambungan pes pateri. Proses penilaian sambungan pateri dengan menggunakan warna akan menjadi lebih mudah kerana warna dan sifat kromatositi merupakan salah satu unsur bagi komunikasi secara visual. Mata manusia bersama-sama dengan otak berfungsi untuk menterjemahkan cahaya kepada warna. Reseptor cahaya dalam mata menghantar maklumat kepada otak yang menghasilkan kepekaan terhadap warna. Newton telah memerhatikan bahawa warna tidak wujud dalam objek. Hal ini adalah kerana permukaan sesuatu objek telah memantulkan beberapa warna dan menyerap warna yang lain. Maka kita hanya dapat melihat warna yang dipantulkan sahaja. Dalam teknologi yang memerlukan pemeriksaan secara visual, kod warna merupakan kaedah yang dapat memberikan maklumat dengan cepat serta warna merupakan kaedah yang paling mudah dalam menyampaikan struktur dan bentuk bahan. Warna telah digunakan secara meluas dalam industri kaca dan seramik (Boschetti et al. 2016; Holgado et al. 2016; Jovaní et al. 2016; Kim \& Kim 2016; Mantovani et al. 2015; Möncke et al. 2014; Nor et al. 2016; Skowroński et al. 2014; Thieme et al. 2016). Terdapat kajian yang cuba untuk mewarnakan sambungan pempaterian (King \& Gulino 1998; Zeng et al. 2011) untuk pelbagai aplikasi (Jiang et al. 2007; Kim 2000; Kim \& Cho 1995). Walau bagaimanapun, sehingga kini belum ada bahan pateri yang berwarna mahupun dokumen yang menunjukkan bahan pateri boleh diwarnakan.

Lapisan sebatian logam (IMC) merupakan suatu lapisan yang tumbuh di antara substrat dan aloi pateri. Lapisan IMC ini merupakan hasilan tindak proses pematerian (by-product). Lapisan ini terbentuk semasa tindak-balas pembasahan sewaktu proses pematerian dan tumbuh membesar dalam keadaan pepejal disebabkan oleh tindakan teraktif terma melalui proses resapan. Dalam kajian lepas, isu tentang pertumbuhan IMC merupakan isu yang sering menjadi perhatian (Choudhury \& Ladani 2016). Lapisan IMC pada antaramuka pateri-substrat merupakan indikasi kebolehbasahan serta ikatan metalurgi bagi sambungan pateri yang baik. Sambungan pateri yang baik adalah penting untuk memastikan kebolehfungsian sesuatu produk elektronik. Walau bagaimanapun, sekiranya lapisan IMC yang terlalu tebal, kerapuhan lapisan IMC akan mengakibatkan kegagalan sambungan dan kebolehharapan yang rendah, seterusnya menyebabkan komponen elektronik tidak dapat berfungsi (Li et al. 2016). Lantaran itu, kebanyakan kajian lepas telah menambahbaik sifat antaramuka pateri contohnya dengan menggunakan karbon nanotiub (CNT) bagi merencatkan pertumbuhan IMC (Mayappan et al. 2016). Kajian ini memfokuskan tentang kesan pigmen pewarna dalam mewarnakan sambungan aloi pateri. Penambahan pigmen pewarna yang berbeza ke dalam bahan pes pateri dijangka dapat memberikan sifat pemukaan aloi pateri yang berlainan. Objektif utama kajian ini ialah untuk menentukan kesan pigmen pewarna ke atas kestabilan antarasambungan pateri bebas plumbum daripada segi pertumbuhan IMC selepas didedahkan dengan ujikaji penuaan sesuhu dengan tempoh yang berbeza.

\section{BAHAN DAN KAEDAH}

Pes aloi pateri SAC 305 dengan komposisi $96.5 \%$ Sn, 3.0\% $\mathrm{Ag}$ dan $0.5 \% \mathrm{Cu}$. Partikel aloi pateri yang digunakan dalam pes pateri adalah berjulat 20-38 $\mu \mathrm{m}$. Dua jenis bahan pewarna digunakan iaitu pigmen hijau (G) dan pigmen bercahaya dalam gelap (GD), masing-masing dengan komposisi 5\% dan $10 \%$ dicampur kepada bahan pes pateri SAC 305. Ujian sinar-X pendaflour (XRF, Bruker) dijalankan untuk menganalisis jenis sebatian yang hadir dalam pewarna yang digunakan ke atas pes pateri SAC 305. Pes pateri SAC305 tanpa pigmen pewarna digunakan sebagai kawalan. Pes pateri berwarna didepositkan pada PCB Cu melalui proses percetakan stencil dan dipaterikan secara aliran semula pada suhu $260^{\circ} \mathrm{C}$. Setelah selesai dipateri, sampel didedahkan kepada uji kaji penuaan sesuhu pada suhu $150^{\circ} \mathrm{C}$ dengan tempoh $200,400,600,800$ dan 1000 jam. Selesai uji kaji tersebut, teknik metalografi digunakan dalam mendapatkan keratan rentas sampel bagi pencirian fizikal. Sampel selepas uji kaji penuaan sesuhu dipotong menggunakan mesin pemotong dengan mata pemotong berlian. Sampel dikepil menggunakan klip sampel sebelum dimasukkan ke dalam acuan cagak. Bahan cagak terdiri daripada serbuk resin pengeras (VersoCit-2 Powder, Struers) dan cecair resin epoksi (VersoCit-2 liquid, Struers) dengan nisbah berat 3:2. Kedua jenis bahan cagak ini digaul perlahan-lahan selama $30 \mathrm{~s}$ untuk percampuran yang homogen, seterusnya dituang ke dalam bekas acuan. Bahan cagak ini akan mengeras pada suhu bilik selama empat jam. Sampel dikeluarkan daripada acuan cagak setelah mengeras dan sedia untuk proses yang seterusnya, proses lelasan. Kertas lelas $\mathrm{SiC}$ (Buehler) daripada gred kasar kepada gred halus (400, 600, 800, 1200, 2000 grit) digunakan bagi proses lelasan. Manakala, semburan berlian bersaiz $1 \mu \mathrm{m}$ digunakan bagi proses penggilapan bagi mendapatkan permukaan sampel yang bebas daripada kesan calar. Pencirian fizikal sampel dijalankan dengan menggunakan alat mikroskop fokus tidak terhingga (IFM, Alicona). Pencerapan mikrostruktur lapisan sebatian antara logam (IMC) dijalankan menggunakan pembesaran sebanyak 100×. Purata ketebalan IMC diperoleh dengan mengambil bacaan ketebalan sebanyak 100 bacaan pada tempat yang berbeza.

\section{KEPUTUSAN DAN PERBINCANGAN}

Pematerian pes aloi pateri dengan pigmen hijau $(G)$ dan pigmen bercahaya dalam gelap (GD) telah berjaya dipaterikan dengan baik pada $\mathrm{PCB} \mathrm{Cu}$. Jadual 1 dan 2 menunjukkan peratusan sebatian yang terdapat di dalam bahan pigmen hijau $(G)$ dan pigmen bercahaya dalam gelap (GD) dengan kandungan yang berbeza. Sebatian yang paling tinggi di dalam pigmen pewarna $G$ ialah barium oksida, BaO manakala bagi pigmen pewarna GD pula ialah aluminium oksida, $\mathrm{Al}_{2} \mathrm{O}_{3}$. Rajah 1 menunjukkan lapisan IMC selepas uji kaji penuaan sesuhu pada $150^{\circ} \mathrm{C}$ selama 0 hingga 1000 jam bagi sampel aloi pateri SAC 305 dengan pigmen pewarna GD sebanyak 5\%. Didapati lapisan IMC 
semakin menebal seiring dengan tempoh penuaan sesuhu. Kajian berkaitan kestabilan lapisan IMC telah menarik perhatian ramai penyelidik. Kestabilan lapisan IMC ini menjadi penunjuk kepada kualiti dan kebolehharapan sesuatu sambungan pateri. Lapisan IMC merupakan suatu sebatian yang mempunyai sifat fizik dan mekanik yang berbeza dengan logam asal ( $\mathrm{Sn}, \mathrm{Ag}, \mathrm{Cu})$. Lapisan IMC yang nipis adalah diperlukan untuk mengekalkan kekuatan mekanik antarasambungan bahan pateri dan substrat melalui mekanisma penguncian antaramuka (interlocking) (Lin et al. 2007). Walau bagaimanapun, akibat tindakan suhu dan masa, contohnya dalam uji kaji penuaan sesuhu, lapisan IMC boleh tumbuh menebal dan menjadikan kekuatan fizik dan mekanik antarasambungan menjadi lemah berikutan sifat terma yang berbeza iaitu pekali pengembangan terma (CTE) yang berubah (Zhang et al. 2017). Perbezaan CTE ini boleh menghasilkan retak terma secara mekanik dan juga ketebalan IMC yang tebal menjadikan kekuatan antarasambungan menjadi lebih rapuh. Antarasambungan yang rapuh adalah berikutan dari sifat asas sebatian IMC yang lebih rapuh berbanding dengan logam asal. Dalam kajian ini, terdapat dua jenis lapisan IMC yang dicerap lapisan bawah yang lebih gelap dan lapisan atas yang lebih cerah. Kedua-dua lapisan yang dicerap ini adalah selaras dengan kajian lepas yang menggunakan bahan pateri yang sama, SAC305 dan substrat $\mathrm{Cu}$ (Hu et al. 2016). Lapisan tersebut direkodkan sebagai $\mathrm{Cu}_{3} \mathrm{Sn}$ bagi lapisan bawah yang gelap dan $\mathrm{Cu}_{6} \mathrm{Sn}_{5}$ bagi lapisan atas yang cerah. Bentuk lapisan IMC yang tumbuh adalah berbentuk lembah dan bergunungganang merupakan bentuk tipikal lapisan IMC seperti yang dilaporkan dalam kajian lepas (Bang et al. 2017). Pembentukan dan pertumbuhan IMC semasa uji kaji dijalankan adalah dipengaruhi oleh pelbagai jenis faktor termasuklah kesan suhu, masa, penggunaan kemasan permukaan serta penambahan unsur ke dalam aloi pateri. Pembentukan IMC adalah melalui proses resapan seperti di dalam persamaan yang berikut:

$$
\begin{aligned}
& 3 \mathrm{Cu}+\mathrm{Sn} \rightarrow \mathrm{Cu}_{3} \mathrm{Sn} \\
& 5 \mathrm{Sn}+6 \mathrm{Cu} \rightarrow \mathrm{Cu}_{6} \mathrm{Sn}_{5}
\end{aligned}
$$

JADUAL 1. Peratusan sebatian di dalam pewarna hijau $(\mathrm{G})$

\begin{tabular}{cc}
\hline Sebatian & Peratus (\%) \\
\hline $\mathrm{BaO}$ & 60.12 \\
$\mathrm{SO}_{3}$ & 27.82 \\
$\mathrm{Fe}_{2} \mathrm{O}_{3}$ & 2.87 \\
$\mathrm{SiO}_{2}$ & 2.00 \\
$\mathrm{SrO}$ & 0.90 \\
$\mathrm{JNa}_{2} \mathrm{O}$ & 0.62 \\
$\mathrm{CuO}$ & 0.45 \\
$\mathrm{CaO}$ & 0.21 \\
$\mathrm{MgO}$ & 0.12 \\
$\mathrm{TiO}$ & 0.09 \\
\hline
\end{tabular}

JADUAL 2. Peratusan sebatian di dalam pewarna bercahaya dalam gelap (GD)

\begin{tabular}{cc}
\hline Sebatian & Peratus $(\%)$ \\
\hline $\mathrm{Al}_{2} \mathrm{O}_{3}$ & 18.23 \\
$\mathrm{ZrO}_{2}$ & 14.10 \\
$\mathrm{SiO}_{2}$ & 11.17 \\
$\mathrm{CaO}$ & 2.43 \\
$\mathrm{Na}{ }_{2} \mathrm{O}$ & 1.56 \\
$\mathrm{P}_{2} \mathrm{O}_{5}$ & 0.76 \\
$\mathrm{Eu}_{2} \mathrm{O}_{3}$ & 0.39 \\
$\mathrm{BaO}$ & 0.35 \\
$\mathrm{MgO}$ & 0.31 \\
$\mathrm{Dy}_{2} \mathrm{O}_{3}$ & 0.25 \\
$\mathrm{SO}_{3}$ & 0.19 \\
$\mathrm{~K}_{2} \mathrm{O}$ & 0.17 \\
$\mathrm{ThO}_{2}$ & 0.07 \\
$\mathrm{Rb}_{2} \mathrm{O}$ & 0.06 \\
$\mathrm{Fe}_{2} \mathrm{O}_{3}$ & 0.05 \\
$\mathrm{CuO}_{2 n}$ & 0.02 \\
$\mathrm{ZnO}$ & 0.01 \\
\hline
\end{tabular}
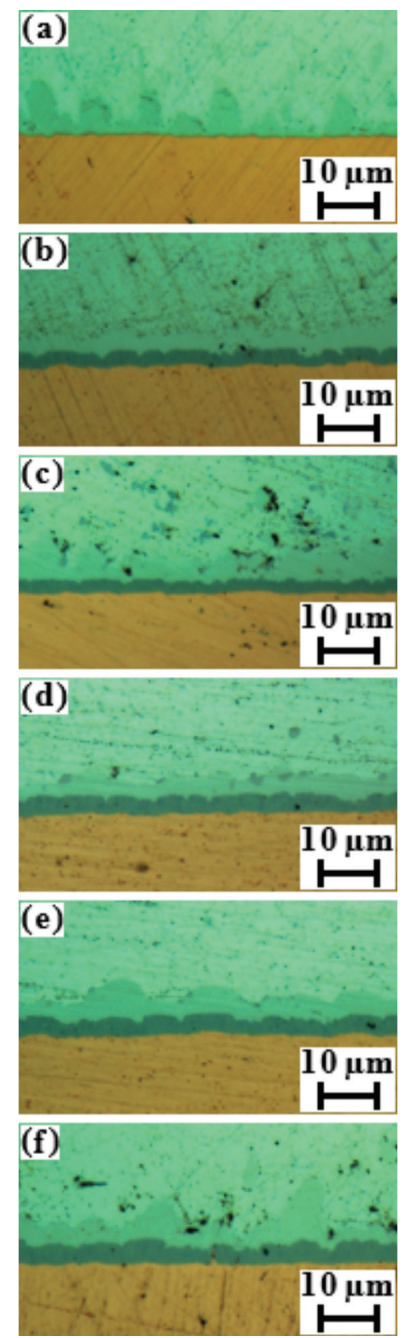

RAJAH 1. Mikrograf lapisan IMC bagi sampel 5\% GD selepas penuaan sesuhu pada $150^{\circ} \mathrm{C}$ selama (a) 0 , (b) 200 , (c) 400 ,

(d) 600 , (e) 800 dan (f) 1000 jam 
Corak pertumbuhan lapisan IMC dengan kandungan pigmen pewarna yang berbeza selepas uji kaji penuaan sesuhu dari 0 hingga 1000 jam ditunjukkan dalam Rajah 2. Berdasarkan Rajah 2, ketebalan lapisan IMC meningkat seiring dengan masa penuaan sesuhu. Dalam kebanyakan literatur, pertumbuhan IMC direkodkan menurut hukum pertumbuhan parabolik dengan mengikut persamaan berikut:

$$
D=k t^{n}
$$

yang mana $D$ ialah ketebalan lapisan IMC; $k$ adalah pemalar kadar pertumbuhan; $t$ adalah masa tindak balas dan $n$ adalah eksponen pertumbuhan. Kebiasaannya, nilai $n$ bagi pertumbuhan secara parabolik adalah bersamaan dengan 2. Walau bagaimanapun, bagi kajian ini, corak pertumbuhan secara linear telah dicerap berbanding dengan pertumbuhan secara parabolik. Didapati bahawa pada suhu $150^{\circ} \mathrm{C}$ dan tempoh penuaan sesuhu selama $1000 \mathrm{jam}$, pertumbuhan lapisan IMC adalah linear. Adalah berkemungkinan pertumbuhan IMC dalam kajian ini akan menuruti pertumbuhan secara parabolik sekiranya tempoh penuaan sesuhu dilanjutkan. Hukum pertumbuhan parabolik ini sangat bergantung kepada eksponen pertumbuhan, $n$ yang dinilaikan sebagai 2 (Burke \& Turnbull 1952). Walau bagaimanapun, terdapat laporan yang menunjukkan nilai $\mathrm{n}$ adalah sangat bergantung kepada komposisi kimia aloi dan julat suhu uji kaji yang digunakan (Humphreys \& Hatherly 2004). Selain itu, terdapat juga laporan menyatakan nilai $n$ bersamaan 1, bahkan nilai tersebut tidak tetap dan berubah-ubah. Begitu juga terjadi dalam kajian ini, iaitu $n$ bersamaan dengan 1 . Oleh kerana pertumbuhan yang berlaku adalah searah, iaitu pertumbuhan ke arah bahan pateri, maka nilai $n$ adalah berkemungkinan 1. Sekiranya ini benar, maka pertumbuhan lapisan IMC dalam kajian ini adalah linear. Pertumbuhan linear, $n$ bersamaan 1 ini bererti bahawa kadar pertumbuhan adalah terhad oleh kadar tindak balas pada tapak pertumbuhan iaitu pada kawasan antaramuka penglogaman dan pateri (Frear \& Tu 2001). Seperkara lagi, lapisan IMC telah tersedia terbentuk sebagai hasilan tindak balas semasa proses pematerian. Rajah 2 merekodkan nilai lapisan IMC yang asal sebelum uji kaji penuaan sesuhu dijalankan adalah sekitar 3-4 $\mu \mathrm{m}$. Kebiasaannya, teori pertumbuhan mempertimbangkan (3), dengan ketebalan asal adalah jauh lebih kecil daripada ketebalan akhir:

$$
D_{0}<<<D_{t}
$$

adalah ketebalan IMC yang asal manakala adalah ketebalan selepas uji kaji penuaan sesuhu. Dalam kajian ini, nilai tidak boleh diabaikan, maka:

$$
D_{t}-D_{0}=k t^{n}
$$

yang mana jika nilai $n$ adalah 1, maka:

$$
\begin{aligned}
& D_{t}-D_{0}=k t \\
& D=k t
\end{aligned}
$$

Seterusnya, penambahan pigmen pewarna $G$ dan GD telah didapati mempercepatkan kadar pertumbuhan lapisan IMC. Ketebalan lapisan IMC bagi semua jenis peratus pigmen pewarna telah meningkat secara linear, seiring dengan masa penuaan sesuhu. Kadar pertumbuhan diwakili oleh kecerunan daripada plot ketebalan IMC dalam Rajah 2, dengan jelas menunjukkan penggunaan pewarna $\mathrm{G}$ di dalam pes pateri lebih mengaruhkan ketebalan IMC berbanding dengan penggunaan pigmen pewarna GD. Berdasarkan plot ketebalan IMC di dalam Rajah 2, nilai kecerunan bagi sampel kawalan ialah $0.0047,5 \% \mathrm{G}$ ialah $0.0069,5 \%$ GD ialah $0.0059,10 \% \mathrm{G}$ ialah 0.0086 dan $10 \%$ GD ialah 0.0074 . Keputusan ini menunjukkan bahawa kecerunan yang menghampiri sampel kawalan ialah sampel 5\% pigmen pewarna GD yang mengambarkan bahawa pertumbuhan IMC bagi sampel berwarna yang paling stabil dengan nilai kecerunan yang paling hampir dengan sampel kawalan. Kandungan pigmen pewarna yang lebih tinggi iaitu sebanyak $10 \%$ telah mengaruhkan pertumbuhan IMC, iaitu menghasilkan lapisan IMC yang lebih tebal berbanding dengan kandungan pigmen pewarna sebanyak 5\%. Keadaan ini dapat diperhatikan pada kedua-dua jenis pigmen pewarna. Ini bermakna kestabilan mikrostruktur bagi sambungan pateri (yang ditunjukkan oleh pertumbuhan IMC yang minimum) yang menggunakan pigmen pewarna adalah lebih rendah dengan antarasambungan pateri yang menggunakan pes pateri tidak berwarna. Maka jenis penggunaan pigmen pewarna daripada segi peratusan komposisi pewarna, jenis pigmen pewarna haruslah diberi perhatian dalam mereka bentuk pes pateri berwarna supaya kualiti dan kebolehharapan adalah bersesuaian dengan aplikasi sambungan pateri tersebut.

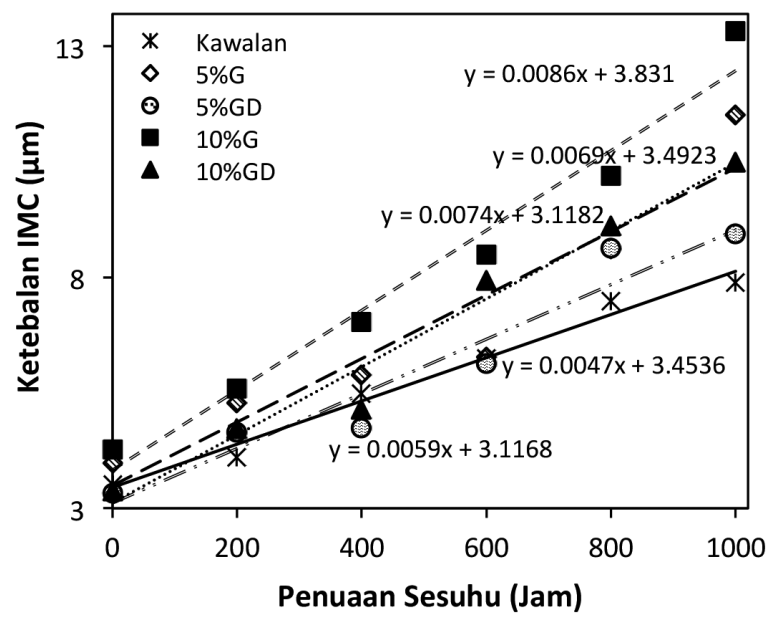

RAJAH 2. Purata ketebalan IMC dengan peratus dan jenis pigmen pewarna yang berbeza selepas penuaan sesuhu pada $150^{\circ} \mathrm{C}$ selama 1000 jam 


\section{KESIMPULAN}

Penggunaan pigmen pewarna telah berjaya menghasilkan sambungan pateri yang berwarna. Aloi pateri dengan pigmen pewarna hijau $(\mathrm{G})$ telah menyebabkan berlaku pertumbuhan sebatian antara logam (IMC) yang lebih tinggi berbanding dengan penggunaan pigmen pewarna bercahaya dalam gelap (GD). Aloi pateri dengan 5\% pigmen GD telah menunjukkan perubahan pertumbuhan IMC yang paling minimum iaitu sebanyak $5.6 \mu \mathrm{m}$ selepas uji kaji penuaan sesuhu pada $150^{\circ} \mathrm{C}$ selama 1000 jam bagi sambungan pateri berwarna. Ini membuktikan bahawa pigmen pewarna GD adalah lebih stabil daripada segi pertumbuhan lapisan IMC akibat tindakan suhu dan masa yang berbeza. Namun begitu, kestabilan pertumbuhan IMC akibat sambungan pateri berwarna adalah lebih rendah jika dibandingkan dengan sambungan pateri tanpa pewarna. Pewarnaan sambungan pateri dengan penambahan pigmen pewarna ke atas pes pateri berkemungkinan dapat diguna pakai dalam pelbagai aplikasi seperti pemeriksaan visual, pengenalpastian, penandaan, piawaian, pengujian dan penilaian terhadap antarasambungan pes pateri dengan mempertimbangkan kestabilan mikrostruktur dan pertumbuhan lapisan IMC supaya tidak menjejaskan kualiti, kebolehharapan dan kebolehtahanan produk elektronik.

\section{PENGHARGAAN}

Penulis merakamkan penghargaan kepada pihak RedRing Solder (M) Sdn. Bhd. atas kolaborasi projek ini serta sumbangan bahan penyelidikan, Universiti Kebangsaan Malaysia (UKM) dan Kementerian Pendidikan Tinggi untuk geran penyelidikan FRGS/1/2017/STG07/UKM/01/3.

\section{RUJUKAN}

Bakar, M.A., Jalar, A., Daud, A.R., Ismail, R., Lah, N.C.A. \& Ibrahim, N.S. 2016. Nanoindentation approach on investigating micromechanical properties of joining from green solder materials. Sains Malaysiana 45(8): 1275-1279.

Bang, J., Yu, D.Y., Ko, Y.H., Kim, M.S., Nishikawa, H. \& Lee, C.W. 2017. Intermetallic compound formation and mechanical property of $\mathrm{Sn}-\mathrm{Cu}-\mathrm{xCr} / \mathrm{Cu}$ lead-free solder joint. Journal of Alloys and Compounds 725: 992-1001.

Boschetti, C., Henderson, J., Evans, J. \& Leonelli, C. 2016. Mosaic tesserae from Italy and the production of Mediterranean coloured glass (4rd century BCE-4th century CE). Part I: Chemical composition and technology. Journal of Archaeological Science: Reports 7: 303-311.

Burke, J.E. \& Turnbull, D. 1952. Recrystallization and grain growth. Progress in Metal Physics 3: 220-292.

Choudhury, S.F. \& Ladani, L. 2016. Local shear stress-strain response of $\mathrm{Sn}-3.5 \mathrm{Ag} / \mathrm{Cu}$ solder joint with high fraction of intermetallic compounds: Experimental analysis. Journal of Alloys and Compounds 680: 665-676.

Frear, D.R. \& Tu, K.N. 2001. Metallurgical factors. Dlm. Area Array Interconnection Handbook, disunting oleh Puttlitz, K.J. \& Totta, P.A. New York: Springer \& Business Media. pp. 1108-1143.

Holgado, P.H., Holgado, M.J., Román, M.S.S. \& Rives, V. 2015. $\mathrm{Ni}-\mathrm{Fe}$ mixed oxides prepared by calcination of layered double hydroxides: Potential ts for the ceramic industry. Ceramics International 41(7): 8451-8460.

Hu, X., Xu, T., Jiang, X., Li, Y., Liu, Y. \& Min, Z. 2016. Effect of post-reflow cooling rate and thermal aging on growth behavior of interfacial intermetallic compound between SAC305 solder and Cu substrate. Appl. Phys. A 122: 278.

Humphreys, F.J. \& Hatherly, M. 2004. Recrystallization and Related Annealing Phenomena. Amsterdam: Elsevier.

Ismail, N., Ismail, R., Abd Aziz, N.I. \& Jalar,A. 2016. Wettability of CNT-doped solder under isothermal aging. Materials Science Forum 857: 76-78.

Jiang, B.C., Wang, C.C. \& Hsu, Y.N. 2007. Machine vision and background remover-based approach for PCB solder joints inspection. International Journal of Production Research 45(2): 451-464.

Jovaní, M., Sanz, A., Beltrán-Mir, H. \& Cordoncillo, E. 2016. New red-shade environmental-friendly multifunctional $t$ based on $\mathrm{Tb}$ and $\mathrm{Fe}$ doped $\mathrm{Y}_{2} \mathrm{Zr}_{2} \mathrm{O} 7$ for ceramic applications and cool roof coatings. Dyes and Pigments 133: 33-40.

Kim, H.K. \& Kim, S.H. 2016. Optical properties of pre-colored dental monolithic zirconia ceramics. Journal of Dentistry 55: $75-81$.

Kim, J.H. 2000. Method and Apparatus for Inspecting Solder Joints. Patent Number: 6,111,602.

Kim, J.H. \& Cho, H.S. 1995. Neural network-based inspection of solder joints using a circular illumination. Image and Vision Computing 13(6): 479-490.

King, C.E. \& Gulino, A.J. 1998. Preformed Solder Parts Coated with Parylene in a Thickness Effective to Exhibit Predetermined Interference Colors. Patent Number: $5,789,068$

Li, Z.L., Li, G.Y., Li, B., Cheng, L.X., Huang, J.H. \& Tang, Y. 2016. Size effect on IMC growth in micro-scale Sn-3.0Ag$0.5 \mathrm{Cu}-0.1 \mathrm{TiO}$, solder joints in reflow process. Journal of Alloys and Compounds 685: 983-991.

Lin, Y.C., Shih, T.Y., Tien, S.K. \& Duh, J.G. 2007. Suppressing $\mathrm{Ni}-\mathrm{Sn}-\mathrm{P}$ growth in $\mathrm{SnAgCu} / \mathrm{Ni}-\mathrm{P}$ solder joints. Scripta Materialia 56: 49-52.

Mantovani, L., Tribaudino, M., Dondi, M. \& Zanelli, C. 2015. Synthesis and color performance of CaCoSi2O6 pyroxene, a new ceramic colorant. Dyes and Pigments 120: 118-125.

Mayappan, R., Hassan, A.A., Ghani, N.A.A., Yahya,I. \& Andas, J. 2016. Improvement in intermetallic thickness and joint strength in carbon nanotube composite $\mathrm{Sn}-3.5 \mathrm{Ag}$ lead-free solder. Materials Today: Proceedings 3: 1338-1344.

Möncke, D., Papageorgiou, M., Winterstein-Beckmann, A. \& Zacharias, N. 2014. Roman glasses coloured by dissolved transition metal ions: Redox-reactions, optical spectroscopy and ligand field theory. Journal of Archaeological Science 46: 23-36.

Nor, N.A.M., Aziz, N., Adnan, A.F.M., Taha, R.M. \& Arof, A.K. 2016. Chromaticity and color saturation of ultraviolet irradiated poly (vinyl alcohol)-anthocyanin coatings. Optical Materials 56: 18-21.

Ren, G., Wilding, I.J. \& Collins, M.N. 2016. Alloying influences on low melt temperature $\mathrm{SnZn}$ and $\mathrm{SnBi}$ solder alloys for electronic interconnections. Journal of Alloys and Compounds 665: 251-260.

Skowroński, Ł., Trzcinski, M., Antończak, A.J., Domanowski, P., Kustra, M., Wachowiak, W., Naparty, M.K., Hiller, T., Bukaluk, A. \& Wronkowska, A.A. 2014. Characterisation of coloured TiOx/Ti/glass systems. Applied Surface Science 322: $209-214$ 
Thieme, C., Waurischk, T., Lin, C. \& Rüssel, C. 2016. Lilac ceramic ts based on $\mathrm{Ba} 0.5 \mathrm{Sr} 0.5 \mathrm{Zn} 2-\mathrm{xNixSi} 2 \mathrm{O} 7$ solid solutions. Ceramics International 42(11): 13035-13040.

Yahaya, M.Z., Ani, F.C., Samsudin, Z., Abdullah, M.Z. \& Mohamad, A.A. 2016. Hardness profiles on Sn-3.0Ag$0.5 \mathrm{Cu}-\mathrm{TiO}_{2}$ composited solder by nanoindentation. Materials Science and Engineering A 669: 178-186.

Zeng, Z., Ma, L. \& Suwa, M. 2011. Algorithm of locating PCB components based on colour distribution of solder joints. Int . J. Adv. Manuf. Technol. 53: 601-614.

Zhang, L., Liu, Z.Q., Yang, F. \& Zhong, S.J. 2017. $\mathrm{Cu}_{6} \mathrm{Sn}_{5}$ whiskers precipitated in $\mathrm{Sn} 3.0 \mathrm{Ag} 0.5 \mathrm{Cu} / \mathrm{Cu}$ interconnection in concentrator silicon solar cells solder layer. Materials 10(4): 327.

Azman Jalar, Maria Abu Bakar* \& Roslina Ismail Institute of Microengineering and Nanoelectronics Universiti Kebangsaan Malaysia 43600 UKM Bangi, Selangor Darul Ehsan

Malaysia
Azman Jalar

School of Applied Physics

Faculty of Science and Technology

Universiti Kebangsaan Malaysia

43600 UKM Bangi, Selangor Darul Ehsan

Malaysia

Najib Saedi Ibrahim \& Mohd Ariffin Ambak Redring Solder (M) Sdn. Bhd.

Lot 17486, Jalan Dua, Taman Selayang Baru 68100 Batu Caves, Selangor Darul Ehsan

Malaysia

*Pengarang untuk surat-menyurat; email: maria@.ukm.edu.my

Diserahkan: 21 September 2017

Diterima: 30 Disember 2017 